\title{
The Scaled Arrival of K-12 Online Education: Emerging Realities and Implications for the Future of Education
}

\author{
JAMES D. BASHAM, SEAN J. SMITH, DIANA L. GREER, UNIVERSITY OF KANSAS AND \\ MATTHEW T. MARINO, UNIVERSITY OF CENTRAL FLORIDA
}

\section{ABSTRACT}

Dramatic increases in $\mathrm{K}-12$ online education for all students, including those in traditionally underserved populations, necessitate a reconceptualization in the way educators plan and implement instruction. In this article the authors examine the complex array of variables and implementation models that must be accounted for during the pivot from a purely brick-and-mortar educational system to one that makes use of both virtual and blended environments. The authors call for enhanced emphasis on instructional goals and design principles, rather than the capabilities of available technology. They conclude that educational leaders and researchers must play a role in three key areas: using technology to enhance the accessibility and usability of curricular materials to meet the needs of different types of learners, advancing the understanding and practices of in-service and pre-service teachers through preparation that focuses on online learning, and fostering collaboration between educational researchers and technology innovators and developers to build a research base that will inform $\mathrm{K}-12$ online education.

\section{INTRODUCTION}

In a frequently cited book based on his noted study of two Silicon Valley high schools, Cuban (2001) documented how computers were generally underutilized or misused in support of traditional forms of instruction. At that time, Cuban argued that use of technology in education was like forcing a square peg in a round hole and predicted that this condition would continue until schools adopted new practices, or technology was designed to better support education.

At the same time as educators began their struggle to use technology effectively, other fields had already begun to meaningfully integrate technology in ways that drastically enhanced, profoundly changed, or significantly reduced the cost of practice. For instance, medicine's integration of technology brought about such innovations as Magnetic Resonance Imaging (MRI), greatly changing medical practices by allowing physicians to look inside a body without performing invasive exploratory surgery. In manufacturing, output in the United States grew substantially as technology was deployed, but costs (by way of jobs) were drastically reduced (de Rugy, 2011).

Fast-forward 12 years since the publication of Cuban's book (2001); the power of technology is beginning to drastically shape the practice of education. The building insurgence of Kindergarten through 12 th grade $(\mathrm{K}-12)$ online education has the potential to alter the landscape of the educational system in ways that are similar to the effects of technological innovations on other fields. Currently 40 states have state-level virtual schools or state-led online initiatives (iNACOL, 2012), 31 states have fulltime virtual or online schools (Watson, Murin, Vashaw, Gemin, \& Rapp, 2012), and several states have reported a continual year-to-year growth rate of over $100 \%$ in the number of students participating in online education (Watson et al., 2012).

This growth pattern is not a simple matter (Kim, Kim, \& Karimi, 2012). It comes at a time of upheaval as efforts to appropriately provide all students with an education that will address the larger needs of a modern society and economy are joined with efforts to meet the criteria of success on traditional assessments of student growth (Basham, Israel, \& Maynard, 2010). For instance, No Child Left Behind (NCLB) (2001) paved the way for school districts to measure student success primarily by paper-based assessments and demanded that schools find ways for nearly all students to demonstrate continual annual progress on these assessments (Ravitch, 2010). This mandate emerged at a time when the evolution of new technology began to drastically alter our cultural practices, and the educational system was looking for new ways to educate students, identified as digital natives, who were learning more from modern technology than ever before (Prensky, 2001). To answer the needs of education (as well as grow new markets), the technology industry has begun to develop and deploy systems for preparing students for higher test-based performance (e.g., Study Island, http://www.studyisland.com/).

Concurrent with educational mandates and new technology, some educational leaders have begun to understand that the world's economy is shifting from regionalized markets to more global, interconnected markets (Darling-Hammond, 2010). The transformation of the workplace requires students to conclude their $\mathrm{K}-12$ school experience with vastly different knowledge and skills in order to be successful (Darling-Hammond, 2010; Zhao, 2012). To support the wider needs of students, programs such as New Tech Schools (http://www.newtechnetwork.org/) use online technology interwoven with a brick-and-mortar school curriculum to support a problem-based learning environment that encourages students to use more college and career ready skills (New Tech Network, 2013). Viewed holistically, K-12 online education is meeting a variety of needs within the educational system, yet for many, the idea of $\mathrm{K}-12$ students receiving some or all of their education through an online system is foreign and new. 
The notion of $\mathrm{K}-12$ online education may come as a surprise to some, but in reality, distance and even online education has been in practice for decades (Cavanaugh Gillan, Kromrey, Hess, \& Blomeyer, 2004). That said, a search of peer-reviewed literature, especially empirical research, provides little descriptive understanding, explanation, or evidence supporting online education (Rice, 2006). In fact, a large majority of the information resides in government and industry driven reports (e.g., Means, Yukie, Murphy, Bakia, \& Jones, 2010) and white papers (e.g., Rhim \& Kowal, 2008). The research literature in peer-reviewed journals is largely limited to studies of $\mathrm{K}-12$ students that were conducted by pioneering researchers such as Cavanaugh (2001), Collins (2001), Frid (2001), and Rice (2006).

The term, $\mathrm{K}-12$ online education, as used in this article, is defined as an educational program where the student learns at least partially through online delivery of content and instruction with some element of student control over time, place, path, and/or pace. Importantly, some of the program may also be supervised in a brick-and-mortar location. As will be discussed later, online education can be divided into two distinct types: completely online (usually called virtual) and blended instruction. In virtual learning environments, students are completely immersed in learning in an online setting. In blended instruction, students are taught through a combination of online instructional delivery and face-to-face experiences.

In this article we review the current conditions and theoretical models associated with $\mathrm{K}-12$ online education and discuss implications of online instruction for educational leaders and practitioners. The discussion is intended to help shape educators' understanding of $\mathrm{K}-12$ online learning as well as create momentum for future research, including more refereed empirical studies. Ultimately, our purpose is to make a contribution to improving online education for all students, including underserved populations.

Much of our understanding is built on the work conducted at the national Center of Online Learning and Students with Disabilities (COLSD). Opened in 2012, the primary mission of COLSD is to conduct research on various dimensions of online learning with respect to accessibility and effectiveness for K-12 learners with disabilities. Although the authors of this article are associated with the COLSD, the principal work is that of the authors only.

\section{CURRENT CONDITIONS IN K-12 ONLINE EDUCATION}

The focus on investing in and developing new technology for the education sector has never been greater (Shah, 2012). In addition, new technology has allowed the world to become more connected and engaged (Shirky, 2011). As a result, information has become decentralized, and school attendance or participation in formal learning activities is no longer required to gain knowledge. For instance, a person with an interest in or a need for help in math can access Khan Academy (http://www.khanacademy.org/) without cost, or use a tool such as Wolfram Alpha (http://www.wolframalpha .com/). The same person, regardless of place, time, or age can also view or even participate in solving complex mathematical problems on math community blogs with renowned mathematicians, such as Fields Medal recipient Timothy Gowers (e.g., http://gowers.wordpress.com/). Likewise, video-conferencing technology (e.g., Skype, Adobe Connect) can bring the teacher to the student's kitchen table offering just-in-time instruction without the student or teacher leaving the confines of their respective homes. All signals agree with Christensen, Horn, and Johnson's (2008) predictions of an emerging disruption of the traditional education sector with online education as a driving force. Specifically, they predict that, by $2019,50 \%$ of all courses in grades 9-12 will be delivered in online learning environments.

Field-based and government indicators provide a clear picture of online education beginning to take shape within the $\mathrm{K}-12$ educational system. For instance, nearly every state has some form of state-led initiatives in online education, and 31 of these states have statewide full-time online schools (Watson et al., 2012). Together, state online schools have seen an ongoing substantial increase from more than 320,000 online $\mathrm{K}-12$ course enrollments during the 2008-09 school year (Wicks, 2010) to 620,000 full-time course enrollments in the most recent school year (Watson et al., 2012). Although virtual schools and online courses in $\mathrm{K}-12$ education are not required, and many do not report the number of students they serve, one source estimates that over 1.8 million students were served during the 2010-11 school year (iNACOL, 2012). Likewise, Watson and colleagues (2012), using a variety of data sources, suggest that the total number of students currently participating in online education is likely closer to several million, or around $5 \%$ of the total school population.

Although $5 \%$ of the student population may not seem large, the reality becomes clearer when the growth rate is further investigated. Measuring online course growth in traditional school districts, EdNet (2011) found that in 2010 only 34\% reported having online courses, yet a year later, $75 \%$ of the districts reported having fully online classes. Moreover, Queen and Lewis (2011) found that $74 \%$ of the districts reported they wanted to significantly increase their online programs in the next one to three years. The planned expansion is not surprising given the high level of interest many students have in taking online courses. According to Watson and colleagues (2012) various states have seen huge growth rates with online student enrollments over the last four years. In fact no state, except Kansas (-5\%), has reported a decrease in online enrollment during the same period. Even in the state of Kansas the number of districts offering completely online programs has tripled in the past two academic years (J. Noble, personal communication, November 30, 2012). Many states, including Wyoming $(+1,038 \%)$, Florida $(+796 \%)$, Utah $(+515 \%)$, Oklahoma $(+337 \%)$, South Carolina (+303\%), Texas (+211\%), Hawaii $(+200 \%)$, Georgia $(+146 \%)$, and California $(+121 \%)$, have reported over $100 \%$ growth in $\mathrm{K}-12$ online enrollments over the same period (Watson et al., 2012). Moreover, some states, such as Arizona and Ohio, are already serving well over 35,000 students in full-time online schools (Watson et al., 2012). 
As could be predicted through the concept of disruptive innovation, the largest populations of students enrolled in online settings are traditionally identified as underserved. For instance, a survey of 2,310 public school districts across all 50 states and the District of Columbia reported that $62 \%$ of online education courses were identified as credit recovery, $47 \%$ as dual enrollment, $29 \%$ as advanced placement, $27 \%$ as technical education, and $65 \%$ were categorized as other academic (Queen \& Lewis, 2011). Not surprisingly, these districts reported the significant majority of online course offerings resided at the high school level. Moreover, the survey found that these public school districts considered the following variables as important or very important when deciding to offer online education: offering courses for credit recovery $(72 \%)$, providing courses not available (71\%), reducing scheduling conflicts (68\%), offering AP or college courses (61\%), meeting the needs of students with disabilities or who are homebound (55\%), providing accelerated credit accumulation for early graduation (42\%), resolving space limitations $(16 \%)$, and generating new revenue (13\%). Finally, as various underserved populations experienced notable increases in online education, the largest year-to-year growth was noted for students with disabilities. This growth was so surprising that Glick (2011) identified it as an area of needed concentration and critical concern for further investigation.

\section{MODELS OF K-12 ONLINE EDUCATION}

As may be expected in a relatively new and fast growing field, various forms or models of practice have emerged. As a whole, online learning can be divided into two primary categories. The first category can generally be defined as fully online, and the second as a blend of online and face-to-face instruction.

Fully online schools and classes are sometimes referred to as virtual. Even though the school may be housed in a brick-and-mortar building, the students never attend this facility. Across the online sector, students enrolled in completely online or virtual schools make up the smallest but growing population. For instance, during the 2011-12 school year, at least 275,000 students attended fully online schools. Reporting the number of students is not required, and therefore, the true student population is likely higher. Over the past few years, virtual schools have averaged an annual growth rate of 15\% (Watson et al., 2012).

By far the largest impact online education has made across the educational system is in the second category, that is, blended learning. According to Christensen, Horn, and Staker (2013) blended learning is distributed among four primary models (see Figure 1). The first of these, the Rotation Model, is described below.

\section{The Rotation Model}

The Rotation Model holds that students move in and out of online instruction based on schedules or teachers' decisions. Christensen et al., (2013) have identified four current approaches to blended instruction within the Rotation Model: station rotation, lab rotation, flipped classroom, and individual rotation.
Figure 1. Blended Learning in Relation to Current and Fully Online Educational Practices (Christensen, Horn, \& Staker, 2013)

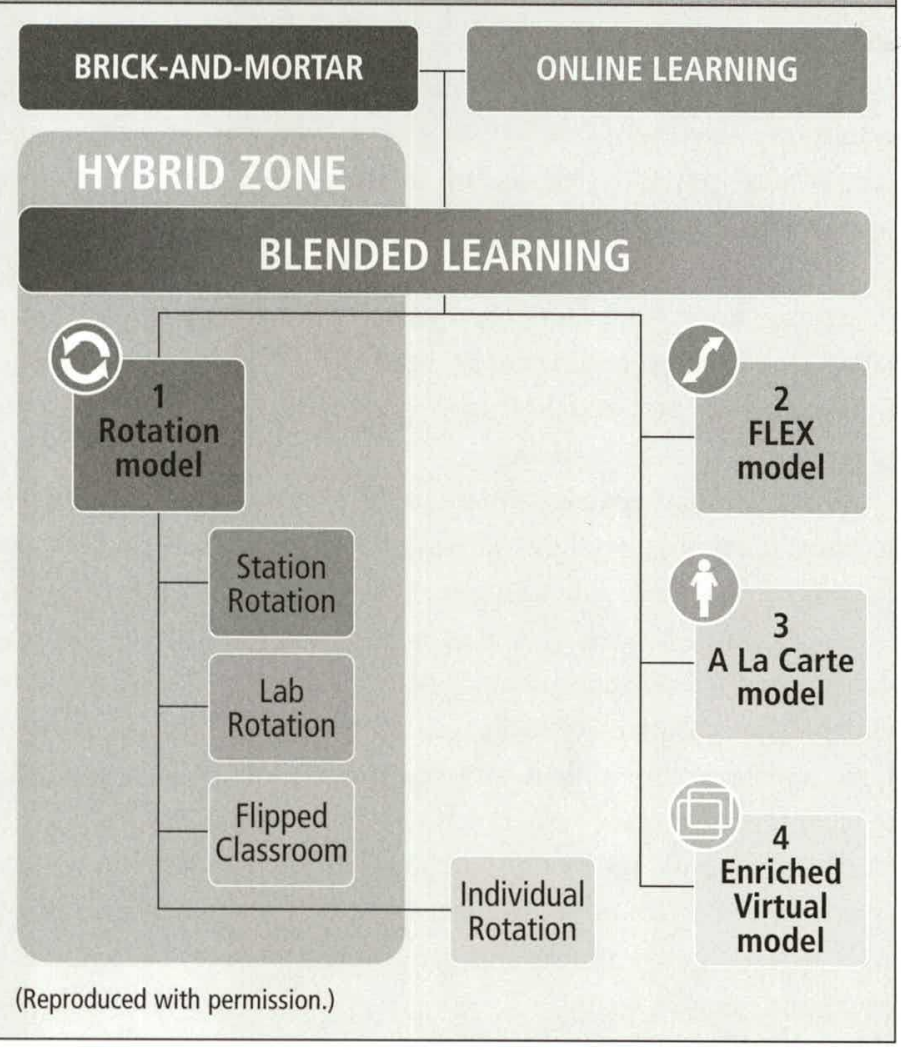

In the station rotation model, students rotate through in-classroom stations (or centers), where at least one of the stations provides for online learning (Christensen et al., 2013). Students can work individually, in small groups, or in large groups to accomplish the tasks established for each station. These tasks can include any number of activities (e.g., read, listen to, watch, write, build, draw) with the intended outcome contributing to student learning goals. An example of this approach is a classroom with multiple stations (or centers) with one of the stations focused on a computer-based, personalized, independent reading program designed to increase achievement among struggling readers. The program allows for students to move at their pace and is specific to their goals, as directed by the intervention and the teacher.

According to Christensen and colleagues (2013) in the lab rotation model, students rotate across multiple locations on a brick-andmortar campus where at least one activity is lab-based and one involves online learning. Within the broader Rotation Model, the lab may be the online component of the rotation, and students rotate across multiple locations within the same campus. In an expansion of the model, these locations may be centrally located on a single brick-and-mortar campus, or they may be beyond the walls of the campus in the physical, rather than the virtual world. For instance, this approach could include a means to support off-campus internships or work experiences. Christensen et al., (2013) noted that the lab rotation model is different from the station rotation model because it takes place in multiple locations, rather than a single room. To clarify, we believe the more important characteristic of 
this approach is that it involves some form of learning lab work. The location of these activities makes no meaningful impact on design of learning; rather, activities are divided between online learning labs and the traditional classroom.

The flipped classroom is a Rotation Model in which the students rotate on a fixed schedule between online delivery of content and instruction, generally outside of the classroom, and face-to-face teacher-guided practice (or projects), generally in a classroom setting (Christensen et al., 2013). This approach flips the way students use homework and class time, wherein homework time (after traditional school time) is spent receiving content information online at the students' own pace, and class time supports practice and problem-solving.

The individual rotation model is like other Rotation Models because it involves students moving between online and teacherfacilitated learning. The difference between this approach and other Rotation Models is that it is personalized around the students' needs (Christensen et al., 2013). These needs may relate to variables such as primary language differences, the pace of instruction, and how the student engages in associated work products (e.g., interdisciplinary projects, traditional papers). In this model, students generally receive instructional delivery through an online system that has some personalization features, supplemented by activities such as seminars and group projects/collaboration in a brick-and-mortar setting.

\section{The Flex Model}

Christensen and colleagues' (2013) second major blended learning model is the Flex Model. Within this model, there are no pre-scheduled instructional times; instead students move through the online content based on their own schedule within a brick-and-mortar location, which is staffed by teachers-of-record and other adults who provide students with needed support in a variety of ways. These include one-on-one or small group instruction in breakout rooms and curriculum-based projects, which could be a small group activity. The main difference between the individual rotation and the Flex Model is that students determine their own instructional schedule in the Flex Model. Primary to this model is that students receive flexible support on an as needed basis. This model relies on personalized online systems, teachers-of-record, and other adults to continuously use data, such as student performance analytics from the online system, to know how to best support each student in accomplishing predetermined goals.

\section{The $A$ la Carte Model}

The $A$ la Carte Model, the third major model presented by Christensen et al. (2013), involves students who choose to supplement their traditional coursework with an online course. Significantly, the actual online learning can be distributed to any location such as a traditional brick-and-mortar school or an off-site location. As we interpret this model, the school may or may not be supporting or even have knowledge of the student taking the supplemental coursework. For instance, a student may be taking a generic programming course at the local high school and then go home and take the free iOS (Apple's mobile operating system) programming course offered by Stanford University in iTunes U.

\section{The Enriched Virtual Model}

Finally, Christensen and colleagues (2013) described the Enriched Virtual Model, a blended education model, which is generally designed to support a completely virtual experience. This approach is designed as a whole-school model in which students spend most of their time online and only periodically come to a brick-and-mortar location for support or enrichment associated with the online education. For instance, a virtual school may offer a brick-and-mortar location where students can physically gather to work on group projects, receive supplemental one-on-one support in an academic area, or attend special workshops on such specific skill areas as interviewing.

These forms of blended instruction demonstrate the breadth of options that schools have for using online instructional technology. However, each of these models treats online technology as only a part of a broader set of instructional choices designed to accomplish learning goals. For instance, in a chemistry course, online instruction may work well for building declarative knowledge about the periodic table of elements, but an in-person lab experience is better suited for discovering the physical properties of chemical interactions, in which such properties as odor and texture are important. Key here is that instructional goals and design, rather than the capabilities and availability of technology, define the relationship of a student to online instruction. To support this concept, Repetto, Cavanaugh, Wayer, and Liu (2010) highlighted the need for online education systems to support the $5 \mathrm{Cs}$ of education (connect, climate, control, curriculum and caring community). In addition, an online learning environment should connect the students with meaningful experiences, provide the appropriate climate for growth and understanding, give the students the ability to control their own learning, offer an engaging curriculum that uses evidence-based teaching practices, and ensure a learning community that is caring. Simply thinking of online education as being driven by technology, rather than instructional design, limits the ability to accomplish the desired outcomes.

\section{THE IMPLICATIONS OF ONLINE LEARNING FOR K-12 EDUCATION}

Transformative policy and practice initiatives have occurred since Cuban (2001) called for schools to adopt new practices for using technology and/or for the technology industry to align the design of innovations with the needs of education. Schools and districts across the nation have adopted online learning practices as a means of serving previously underserved students (e.g., credit recovery and advance placement courses). Further, many schools have integrated online technology with face-to-face instructional activities for better learning outcomes among all students. Likewise, the technology industry has responded to Cuban's call by 
incorporating pedagogically appropriate features (e.g., integration of learning supports in video games, text readers, and other tools integrated in web systems) to better support education.

Online education has become an impetus for major transformation in $\mathrm{K}-12$ education. However, before a complete disruption occurs, we believe district/building leadership, teachers, teacher educators, educational leaders, and researchers should move quickly to purposefully shape a modern learning environment that makes use of online and blended practices. Therefore, we believe three specific efforts require the attention of education leaders and researchers:

1. Move schools toward a more purposeful understanding that technology use is only one part of sound instructional design.

2. Develop in-service and pre-service teachers' skills for designing and applying purposeful instructional design that makes use of technology as well as pedagogical strategies to achieve desired learning objectives.

3. Work with technology innovators and developers to build a research base of online tools as well as instructional methods for supporting the needs of all learners, including those with disabilities and those in other underserved populations.

\section{A More Purposeful Understanding of Technology in Instructional Design}

Consistent with Cuban's earlier findings, a recent study found that $97 \%$ of teachers reported having one or more computers in their classroom, yet, only $29 \%$ reported technology use during instruction on a regular basis (Gray, Thomas, Lewis, \& Tice, 2010). Educational leaders must help schools move beyond the acquisition of technology for technology's sake and toward more purposeful use of the available technology. Decades of research support the idea that technology must be integrated with effective instructional design that includes purposeful strategies in order to produce student learning (e.g., Papert, 1980; 1994; Papert \& Harel, 1991; Sandholtz, Ringstaff, \& Dwyer, 1994).

In the context of the rapid infiltration of online technology delivery systems, the same risk of underutilization or misuse of technology exists. Unless online learning systems are placed in classrooms for pedagogically appropriate purposes, and rely on research-based principles of instructional design, teachers and students are less likely to benefit from them. Too often educators think the technology will provide the needed engagement and instruction without much consideration of a host of other instructional variables (Carnahan, Basham, \& Musti-Rao, 2009). When educators rely solely on technology to provide for student learning, and the desired outcomes are not realized, the technology, rather than the instructional design, is viewed as the cause of the failure. Appropriate technology use requires a purposeful design that accounts for such environmental factors as existing learner variability, desired instructional goals, outcome measures, and the use of both instructional strategies and technology/tools to accomplish the desired outcomes (Basham, Meyer, \& Perry, 2010).
The evidence-based instructional design framework Universal Design for Learning (UDL) (CAST, 2011), for example, proactively addresses learner variability within the educational environment. Barriers (e.g., cultural, physical, social, cognitive) that limit the accessibility of the curricular materials are identified and circumvented at the outset of the design process using multiple means of representation, action, expression, and engagement. Further, UDL supports the notion that student variability is not limited to disability. This is different from many design frameworks that force students to conform to the system, rather than providing for the system to adapt to the student. Within UDL students are provided with multiple ways to engage, access content/information, and demonstrate understanding (CAST, 2011).

In practice, UDL uses both technological tools and instructional strategies in a "backwards design" process to support desired outcomes (UDL-IRN, 2011). Within this framework, educators identify the instructional goals and design the measures of success and the instructional experience that consider learner variability as well as the potential barriers within the content and the environment. To provide for variability and to overcome barriers, the learning experience contains multiple means for students to engage, multiple means in the way content is represented to the student, and multiple ways by which the student can demonstrate understanding of the content. Upon delivering the instruction, formative assessment data are continually gathered and used to inform the educators on the success of the design. An iterative process of design is used to achieve the desired learning outcomes and allow for incremental changes to be made in the instruction and/or the environment to maximize outcomes.

Unfortunately, Stahl, Smith, and Basham (2012) found that $\mathrm{K}-12$ online learning providers are lacking key accessibility and usability features that support the implementation of UDL (CAST, 2011). Moreover, without providing students and teachers with key strategies for how to use the online curriculum (e.g., predict, rewind, pause, use in conjunction with this concept map), lessons that integrate online tools can actually cause more harm than good. We suggest that educational leaders place more emphasis on acquiring and using online learning technology that operationalizes personalized environments and embrace the concept of learner variability regardless of student abilities, disabilities, language, or learning preferences. As a starting point, leaders should consider how both tools and strategies are purposefully used to achieve desired outcomes. As a framework, UDL provides a research-based foundation for thinking about, applying, and building personalized learning environments.

\section{In-service and Pre-service Teacher Education}

As previously indicated, schools risk underutilization or misuse of technology if the systems are not integrated with sound instructional design. Even so, the risk is not fully mitigated nor opportunities fully realized unless teachers are prepared to use the technology, including online and blended learning, as well as instructional strategies to yield the desired outcomes. Too many 
teacher educators and professional development providers have been slow or lacking in integrating technology into the curriculum and the instruction that serve as models. Over a decade ago, the well-documented seminal research of Moursund and Bielefeldt (1999) found that one of the largest contributing factors to a teacher's lack of technology use during instruction was lack of understanding of how to appropriately use technology in instructional practice. More recently, a survey conducted by Gray and colleagues (2010) reported that very few teachers learned how to use computing technology in undergraduate and graduate education classes. So we are not surprised that $78 \%$ of the teachers reported that they still needed to learn how to independently use technology in their classrooms. Overall, we should be disappointed by the small progress that has been made in teacher preparation and staff development for using technology in instruction.

To address these deficiencies, a number of initiatives seek to require teacher education students and current educators to reflect comprehensively on how technology applications will interface with pedagogical principles, the structure of the content, and the students' individual learning needs (Smith \& Okolo, 2010). Koehler and Mishra (2005) have developed an instructional design framework known as technological pedagogical content knowledge (TPACK) that seamlessly integrates technology, content, and pedagogy for design and delivery of various types of content. For the past seven years, TPACK has expanded from a conceptual framework to an integrated instructional approach that includes ways to measure teacher technology competency (Archambault \& Crippen 2009; Schmidt et al., 2009). Educators who benefit from the TPACK framework recognize that technology is not a tool that can or should be thoughtlessly added to existing instruction. Instead, educators should select pedagogies that are a logical match for enhancing and enriching the content (e.g., Koehler \& Mishra, 2005; Shulman, 1987). Technology should be considered only if this tool will interface with the selected pedagogy to help shape and deliver content in a way that would not possible without the use of technology.

While TPACK (Koehler \& Mishra, 2005) is an excellent framework to offer teacher educators and school-based professionals an approach to expanding teacher technology competency, it is limited in the virtual learning paradigm. TPACK seeks to further technology application tied to effective instruction (e.g., pedagogy and content) in order to expand technology integration for the teacher and students. In blended and virtual models, learning is embedded in a system that requires a shift in how one teaches within this new learning structure. Thus, while Koehler and Misha's (2005) TPACK provides a stable foundation for understanding technology integration, especially in supporting teacher education and professional development, a more complete solution is needed for advancing teacher skill development required for current blended and virtual classrooms.

Instead, as current standards indicate (e.g., iNACOL, 2011), teachers need the skills to plan, design, and incorporate strategies that encourage active learning, interaction, participation, and collaboration in the online environment. They also need to develop skills that promote and offer regular, prompt, and ongoing feedback as well as the ability to construct and provide clear expectations to the learner and the adult (e.g., parent) who is supporting the child at home. In the virtual online environment particularly, teachers are increasingly required to develop collaborative as well as consultation skills to further engage, support, and empower the parent or adult in the home who is supporting, motivating, and reinforcing the student on a daily basis. Unlike brick-and-mortar settings, our initial findings indicate that virtual learning is engaging the parent or the adult as a co-teacher or at the very least, a paraeducator, and depending on the parent to implement instructional activities.

With respect to online learning, both practice and industry have surpassed the mindset, ability, and standards within the field of teacher education to understand the dynamics of the modern classroom in general, and online and blended learning in particular. At least two reasons for this lag come to mind. First, higher education may not have the resources to develop or attract and retain leaders who can provide the vision upon which to act. Second, higher education is often tied to slower moving entities such as state legislatures and accrediting boards, and may be moving toward the vision at a slower pace than industry and practice. It is critical that teacher education catch-up and even surpass the current practices of the field. A primary role of teacher education should be to provide leadership for practice as well as supporting the necessary open mindset for adopting new pioneering models. Without this leadership both future and current educators have limited models upon which to base their practice.

\section{A Research Base of Online Tools and Instructional Methods for Supporting All Types of Learners}

The empirical evidence to inform applications of technology in teacher preparation is either absent or in short supply (Lawless \& Pellegrino, 2007). Frequently, the evidence presented to support the use of technology in teacher preparation takes the form of satisfaction reports from users (Clark, 2009). Many technologybased teaching methods do not specify a theoretical framework that provides the basis for, and justification of, the specific design features of the recommended interventions, surely a missed opportunity when considering the design and instructional implications of blended/online learning (Clark, 2009). In addition, while the majority of studies of technology in teacher education focus on user perceptions (Heilson, 2010), of those that do report student learning, the great majority report outcomes with technology in comparison to learning without technology (Schmidt et al., 2009).

In $\mathrm{K}-12$ education, currently $75 \%$ of the districts offering online learning are associated with or even managed and staffed by for-profit companies rather than public education entities (iNACOL, 2012). That is, when districts begin offering online services they often contract with a company to provide the primary content, the instruction, and sometimes the instructional personnel 
(iNACOL, 2012). From a student perspective, nearly all systems follow the same routine in which the student login and are directed through a series of instructional modules. Interestingly, these prepackaged modules are similar to those advocated by Skinner (1986) over 25 years ago. As Skinner demonstrated, machinedriven modules have the potential to rapidly yield powerful learning outcomes, especially with superficial learning (Eysink \& de Jong, 2011). However, this type of technology also has the potential to drastically shape the workforce within education.

Unfortunately, prepackaged materials are often deployed in $\mathrm{K}-12$ online education with little attention to empirical researchbased design principles, instructional strategy integration, or teacher understanding. This dynamic has never been seen before in education. Our intent is not to say that online education companies are harmful to the system, but that as online education moves forward, educational leaders and researchers need to begin partnering with developers to support the design of better systems. The developers would benefit from reaching out to researchers and innovators in the field to better support the development of more evidence-based, personalized systems that meet complex student needs.

Perhaps one of the reasons industry leaders have moved ahead without partnerships with educational researchers is that foundational arguments regarding the approach to technology use in education have not been resolved. An example is the difference between a constructivist approach advocated by Papert and colleagues (Papert, 1980; 1994; Papert \& Harel, 1991) and the behaviorist approach advanced by Skinner (1986). The inability to offer a common sense and real-world balance between dichotomous positions limits our own capacity to move forward as a field. This position also renders the field nearly powerless to cooperate, question, or purposefully respond to a company that wants to place the next "shiny widget" in schools. Rather than jumping into technology systems that recognize only one approach, educational researchers must investigate ways to provide for the development of different types of learners. At this point in time, we believe that blended environments provide a more balanced approach to online learning, and research initiatives to investigate and validate such approaches are vital next steps.

Another possible obstacle to industry-research partnerships is the inability to adopt more nimble and pragmatic research designs. To develop fruitful relationships, educational researchers must find ways to move at a more rapid pace to identify and implement purposeful research designs. Research that investigates both evidence-based practices as well as solutions for realworld learning environments is needed. For instance, research such as A/B testing provides a means to rapidly study design attributes of systems and system features for effects variables including student engagement and/or knowledge attainment (U.S. Department of Education, Office of Educational Technology, 2012). Moreover, methodologies such as Design-Based Research (DBR) or Design-Based Implementation Research (DBIR) provide means to investigate how technology and strategy are purposefully integrated and used in real-world environments to produce desired outcomes (Basham, Meyer, et al., 2010). Together A/B testing and DBR support a research structure to rapidly investigate meaningful instructional designs solutions for meeting the needs of many types of students.

Collaborative partnerships among developers, researchers, and schools are required to support the needed technology innovations and practical real-world pedagogical solutions to harness the power of online instruction. If the field desires better systems, we cannot sit idly by waiting for someone to develop them. Rather, we must become more involved in demanding as well as working with developers to design systems that are framed around validated instructional design frameworks, such as UDL (CAST, 2011). For instance, over the last few years, university researchers have been working with Filament Games (http://www.filamentgames.com/) to design UDL-based video games (see Marino, et al., 2012). Within this collaboration academic researchers work alongside Filament video game developers to critique and offer suggestions for the embedded features needed to support UDLaligned video games. The researchers then study the video games to validate their design and efficacy to meet learner variability within classroom settings. This collaboration has produced awardwinning video games that are effective for meeting educational needs across a variety of learners.

\section{CONCLUSION}

More than a decade ago, Cuban (2001) challenged the field of education to adopt new practices, and the technology industry to better support education for the benefit of students across the nation. Since that time, online and blended learning have virtually exploded onto the $\mathrm{K}-12$ education scene and continue to grow rapidly. We believe that leadership is required if online and blended learning is to meaningfully impact education. A further need exists for a broader understanding of student variability and instructional design, and the development of teachers who are competent in the modern learning environment. Critical to all these outcomes is collaboration across the technology and educational research sectors. Our hope is that this discussion will help to shape our understanding as well as provide momentum for further investigation that leads to changes for the benefit of teachers and students, including underserved populations.

\section{References}

Archambault, L., \& Crippen, K. (2009). Examining TPACK among K-12 online distance educators in the United States Contemporary Issues in Technology and Teacher Education, 9(1). Retrieved from http://www .citejournal.org/vol9/iss1/general/article2.cfm.

Basham, J. D., Israel, M., \& Maynard, K. (2010). An ecological model of STEM education: Operationalizing STEM for all. Journal of Special Education Technology, 25(3), 9-19.

Basham, J. D., Meyer, H., \& Perry, E. (2010). The design and application of the digital backpack. Journal of Research on Technology in Education, 42(4), 339-359. 
Carnahan, C., Basham, J., \& Musti-Rao, S. (2009). A low-technology strategy for increasing engagement of students with autism and significant learning needs. Exceptionality, 17, 76-87.

Cavanaugh, C. S. (2001). The effectiveness of interactive distance education technologies in K-12 learning: A meta-analysis. International journal of Educational Telecommunications, 7(1), 73-88.

Cavanaugh, C., Gillan, K., Kromrey, J., Hess, M., \& Blomeyer, R. (2004). The effects of distance education on $K-12$ student outcomes: A metaanalysis. Naperville, IL: Learning Point Associates.

Center for Applied Special Technology (2011). Universal Design for Learning guidelines version 2.0. Wakefield, MA: CAST.

Christensen, C. M., Horn, M. B., \& Johnson, C. W. (2008). Disrupting class: How disruptive innovation will change the way the world learns. New York, NY: McGraw-Hill.

Christensen, C. M., Horn, M. B., \& Staker, H. (2013) Is k-12 blended learning disruptive? An introduction of the theory of hybrids. San Mateo, CA: Clayton Christensen Institute for Disruptive Innovation. Retrieved from http://www.christenseninstitute.org/wp-content /uploads/2013/05/Is-K-12-Blended-Learning-Disruptive.pdf.

Clark, R. E., (2009). Translating research into new instructional technologies for higher education: The active ingredient process. Journal of Computing in Higher Education, 21, 4-18.

Collins, J. (2001). Using the Internet as a distance education tool in selected secondary school areas. Journal of Research on Computing in Education, 33(4), 431-456.

Cuban, L. (2001). Oversold and underused: Computers in the classroom. Cambridge, MA: Harvard University Press.

Darling-Hammond, L. (2010). The flat world and education: How America's commitment to equity will determine our future. New York, NY: Teachers College Press.

de Rugy, V. (2011). U.S. Manufacturing: Output vs. jobs since 1975. Arlington, VA: Mercatus Center, George Mason University. Retrieved from http://mercatus.org/publication/us-manufacturing-output-vs-jobs1975.

diSessa A., \& Abelson, H. (1986). BOXER: A reconstructible computational medium. Communications of the ACM, 29, 859-868.

EdNet (2011). State of the K-12 market 2011: K-12 education and the education industry. Retrieved on May 4, 2012 from http://www.schooldata.com/pdfs/StateofK12Market_Part3_Intro.pdf.

Eysink, T. H., \& de Jong, T. (2011). Does instructional approach matter? How elaboration plays a crucial role in multimedia learning. Philadelphia, PA: Routledge.

Frid, S. (2001). Supporting primary students' online learning in a virtual enrichment program. Research in Education, 66, 9-27.

Glick, D. B. (2011) The demographics of online students and teachers in the United States 2010-11. Retrieved from http://www.glickconsulting .com/sites/default/files/images/Online_Demographics_Glick_2011 .pdf.

Gray, L., Thomas, N., Lewis, L., \& Tice, P. (2010). Teachers' use of educational technology in U.S. public schools: 2009, First Look, 1-70.

Heilson, S. B. (2010). What is the academic efficacy of podcasting? Computer \& Education, 55, 1063-1068.

International Association for K-12 Online Learning [iNACOL] (2011). National standards for quality online teaching Version 2.O., Vienna, VA: Author.

International Association for K-12 Online Learning [iNACOL]. (2012). Fast facts about online learning. Retrieved from http://www.inacol.org
/cms/wp-content/uploads/2012/11/iNACOL_fastfacts_October _2012.pdf.

Kim, P., Kim, F. H., \& Karimi, A. (2012). Public online charter school students: Choices, perceptions, and traits. American Educational Research Journal, 49(3), 521-545.

Koehler, M. J., \& Mishra, P. (2005). What happens when teachers design educational technology? The development of Technological Pedagogical Content Knowledge. Journal of Educational Computing Research, 32(2), 131-152.

Lawless, K. A., \& Pellegrino, J. W. (2007). Professional development in integrating technology into teaching and learning: Knowns, unknowns, and ways to pursue better questions and answers. Review of Educational Research, 77, 575-614.

Marino, M. T., Israel, M., Beecher, C. C., \& Basham, J. D. (2012). Students' and teachers' perceptions of using videogames to enhance science instruction. Journal of Science Education and Technology. doi: 10.1007/s10956-012-9421-9.

Means, B., Yukie, T., Murphy, R., Bakia, M., \& Jones, K. (2010). Evidencebased practices in online learning: A meta-analysis and review of online learning studies. U.S. Department of Education. Retrieved from www.ed.gov/about/offices/list/opepd/ppss/reports.html.

Moursund, D., \& Bielefeldt, T. (1999). Will new teachers be prepared to teach in a digital age? A national survey on information technology in teacher education. Santa Monica, CA: Milken Exchange on Education Technology and the International Society for Technology in Education.

New Tech Network (2013). Retrieved from http://www.newtechnetwork.org/.

Papert, S. (1980). Mindstorms: Children, computers, and powerful ideas. New York, NY: Basic Books.

Papert, S. (1994). The children's machine: Rethinking school in the age of the computer. New York, NY: Basic Books.

Papert, S., \& Harel, I. (1991). Situating constructionism. Constructionism, (pp. 193-206). New York, NY: Ablex Publishing Corporation Retrieved from http://www.papert.org/articles/SituatingConstructionism.html.

Prensky, M. (2001). Digital natives, digital immigrants. On the Horizon, 9(5), $1-6$.

Queen, B., \& Lewis, L. (2011). Distance education courses for public elementary and secondary school students: 2009-10 (NCES 2012-008). Washington, DC: U.S. Department of Education, National Center for Education Statistics, Government Printing Office.

Ravitch, D. (2010). The death and life of the great American school system: How testing and choice are undermining education. New York, NY: Basic Books.

Repetto, J., Cavanaugh, C., Wayer, N., \& Liu, F. (2010). Virtual high schools: Improving outcomes for students with disabilities. The Quarterly Review of Distance Education, 11(2), 91-104.

Rhim, L. M. \& Kowal, J. (2008). Demystifying special education in virtual charter schools. Primers on Special Education in Charter Schools. Retrieved from http://www.charterschoolcenter.org/.

Rice, K. L. (2006). A comprehensive look at distance education in the K-12 context. Journal of Research on Technology in Education, 38(4), $425-448$.

Sandholtz, J. H., Ringstaff, C., \& Dwyer, D. C. (1994). Student engagement: Views from technology-rich classrooms. Retrieved from http://www .apple.com/nl/images/pdf/acotlibrary/rpt21.pdf.

Schmidt, D. A., Baran, E., Thompson, A. D., Mishra, P., Koehler, M. J., 
\& Shin, T. S. (2009). Technological pedagogical content knowledge (TPACK): The development and validation of an assessment instrument for preservice teachers. Journal of Research on Computing in Education, 42(2), 123.

Shah, N. (2012, March 7). Start-ups seek to master the education market: The increasing flow of venture capital into $\mathrm{K}-12$ and heightened interest in educational technology are creating opportunities for market newcomers. Education Week. Retrieved from http://www.edweek .org/ew/articles/2012/03/07/23biz-startup.h31.html.

Shirky, C. (2011). Cognitive surplus: How technology makes consumers into collaborators. New York, NY: Penguin Books.

Shulman, L. (1987). Knowledge and teaching: Foundations of the new reform. Harvard Educational Review, 57(1), 1-22.

Skinner, B. F. (1986). Programmed instruction revisited. The Phi Delta Kappan, 68(2), 103-110.

Smith, S., \& Okolo, C. M. (2010). Response to intervention and evidence-based practices: Where does technology fit? Learning Disability Quarterly, 33, 257-272.

Snyder, T. D., \& Dillow, S. (2012). Digest of education statistics 2011 (NCES 2012-001). Washington, DC: U.S. Department of Education, National Center for Educational Statistics. Retrieved from http://nces.ed.gove/pubsearch.

Stahl, S., Smith, S. J., \& Basham, J. (2012, October). Accessibility of online learning through the UDL lens. Presented at iNACOL Annual Conference, Virtual School Symposium, New Orleans, LA.

The No Child Left Behind Act of 2001 (2001). Pub. L. No. 107-110.

UDL-IRN (2011). Critical Elements of UDL in Instruction (Version 1.3). Lawrence, KS: Author Retrieved February 25, 2012 from http://udlirn.org/storage/resources/Critical_Elements1.3.pdf.

U.S. Department of Education, Office of Educational Technology. (2012). Expanding evidence approaches for learning in a digital world. Washington, DC: Author. Retrieved from http://www.ed.gov /edblogs/technology/files/2012/12/Expanding_Evidence_Approa ches_DRAFT.pdf.

Watson, J., Murin A., Vashaw, L., Gemin, B., \& Rapp, C., (2012). Keeping pace with $\mathrm{K}-12$ online \& blended learning: An annual review of policy and practice. Durango, CO: Evergreen Education Group.

Wicks, M. (2010). A national primer on K-12 online learning (version 2). Vienna, VA: iNACOL. Retrieved from http://www.inacol.org / cms/wp-content/uploads/2012/11/iNCL_NationalPrimerv 22010-web1.pdf.

Zhao, Y. (2012). World class learners: Educating creative and entrepreneurial students. Thousand Oakes, CA: Crowin.

\section{Authors' Note}

The information and analyses reported in this paper were gathered by the Center on Online Learning and Students with Disabilities, a grant from the Office of Special Education Programming, US Department of Education \#H327U110011. However, the contents do not necessarily represent the policy of the US Department of Education, and you should not assume endorsement by the Federal Government. Project Officer, Celia Rosenquist.

James D. Basham is an associate professor in the Department of Special Education at the University of Kansas. Professor Basham may be reached at jbasham@ku.edu.

Sean J. Smith is an associate professor in the Department of Special Education at the University of Kansas. Professor Smith may be reached at sjsmith@ku.edu.

Diana L. Greer is an assistant research professor in the Center for Research on Learning at the University of Kansas. Professor Greer may be reached at dgreer@ku.edu.

Matthew T. Marino is an associate professor in the Department of Child, Family, and Community Sciences Professor at University of Central Florida. Professor Marino may be reached at Matthew.Marino@ucf.edu. 